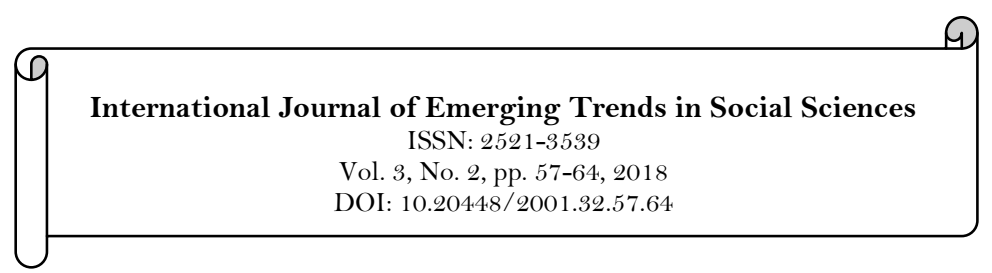

\title{
The Dreyfus Affair and its Reflection in Ladino Literature
}

\author{
Nitsa Dori ${ }^{1}$ \\ ${ }^{1}$ Head of the Department of Early Childhood, Shaanan Academic College, Haifa, Israel. \\ Email:nitsa.dori@gmail.com
}

\begin{abstract}
The Dreyfus Affair took place in the fall of 1894, when secret documents sent by a French officer to the attaché of the German embassy in Paris fell into the hands of the French intelligence services. Based on some similarity in the handwriting, and apparently also because of anti-Jewish prejudice, the intelligence service heads suspected Alfred Dreyfus, a Jewish officer in the French army. The court unanimously found Dreyfus guilty of treason, and he was sentenced to be stripped of his rank and to life imprisonment. The purpose of this article is to reflect the literary expression of the Dreyfus Affair in Ladino literature. The article will discuss several genres of literature in Ladino about the Dreyfus Affair during different periods: two historical novels, two plays, and a newspaper article, while examining the correspondence between the different compositions.

Keywords:

The dreyfus affair

Ladino literature

Ladino novels

Ladino plays

Ladino newspaper.

Licensed:

This work is licensed under a

Creative Commons Attribution

4.0 License.

Publisher:

Scientific Publishing Institute
\end{abstract}

\section{Literature Review}

\subsection{The Dreyfus Affair - Historical Background}

Kleeblatt (1987) is one of the books that encompasses all aspects of the affair, and serves as a yardstick for understanding the popular antisemitism that accompanied the Dreyfus Affair, and even preceded it by many years. Kleeblatt notes in his book that it is impossible to understand this antisemitism in isolation from other important historical developments - the increase and spread of anti-Jewish feelings in France were part of the unusual politicization of the Western world during the nineteenth century; the more the Jews integrated into the local society, the more the old bitterness against them increased. The Dreyfus Affair took place in the fall of 1894, when secret documents sent by a French officer to the attaché of the German embassy in Paris, fell into the hands of the French intelligence services. Based on some similarity in the handwriting, and apparently also because of anti-Jewish prejudice, the intelligence service heads suspected Alfred Dreyfus, a Jewish officer in the French army. The court unanimously found Dreyfus guilty of treason, and he was sentenced to have his rank removed and to life imprisonment. In January 1895, Dreyfus was stripped of his rank in a humiliating public ceremony, while he continued to declare his innocence. The masses, incited by the antisemitic press, responded with curses against Dreyfus and the Jews. Dreyfus was exiled to the desolate Devil's Island in West Africa, and held there under cruel conditions of imprisonment, even though the German ambassador had meanwhile informed the French government that Germany had had no contact with Dreyfus. The entire incident and ceremony left a deep impression on a young Jewish journalist named Theodor Herzl, who had been present at the ceremony where Dreyfus was dishonorably discharged, and he decided to convene a national congress to solve the Jewish problem.

Shortly after Dreyfus's imprisonment, the new head of the French intelligence services, Lieutenant Colonel Picquart, understood that something was crooked about Dreyfus's trial. Picquart was punished by imprisonment for having interfered, contrary to military law. Three war ministers resigned, one after the other, because they refused to reopen the case. The battle for Dreyfus seemed lost, but then Émile Zola, a writer and journalist, published an open letter to the president of the republic, entitled "J'accuse" [I accuse], in which he accused Dreyfus's accusers — the entire military and military courts elite—of a malicious false charge. The court convicted Zola of libel, but his article greatly influenced public opinion. Following a new trial, Dreyfus was exonerated from all guilt, and was restored to his position in the French army in line with his 
request. The true spies were caught. One, Henry Fabris, committed suicide in his prison cell, and the second, Esterhazy, fled from France (Kleeblatt, 1987).

\subsection{The Dreyfus Affair in World Literature - A Review}

The Dreyfus Affair produced important literary works in the world.

Rolland (1898) is a play, the plot of which takes place at the French military headquarters. D'Oyron is an officer in a revolutionary army, who had false charges brought against him accusing him of being a traitor. The person who devised the false accusation is Verrat, a demagogue, who made a living as a pork butcher in civilian life, and was also one of the revolutionary army officers who hated D'Oyron, the aristocrat, since he was a member of "another race". The play ends with D'Oyron being executed by a firing squad behind the scenes, while Teulier, a third officer, who tried to defend D'Oyron, is sitting waiting for his punishment. The parallelism between the events and main figures in the Dreyfus Affair and the plot and characters in "The Wolves" is clear; Rolland has consequently used the disguise of a historical drama taking place in a "different" time and "different" place to create an exact replica of the Dreyfus Affair.

In Zola (1903) the story begins in a small French town at the beginning of the twentieth century. Simon, a Jewish schoolmaster in a public school, is convicted, despite his innocence, of the rape and cruel murder of his ten year old nephew - a Catholic who attended a monastery school. The true murderer is Brother Gorgias, a teacher at the school, but his superiors protect him. The hero of the story, Marc Froment, is a schoolmaster at the public school, who believes in Simon's innocence, and sets out on a battle to prove it.

In France (1902) we encounter Bergeret, a professor of classical languages. In a conversation between Bergeret and another professor, it turns out that there are two people in the provincial town who believe that Dreyfus is innocent: one is a member of the country nobility, who comes to get advice from Bergeret about educating his son, and offhandedly tells him his views about the "traitor", and the second is a carpenter who puts up bookshelves in Bergeret's apartment and praises him at the same time for supporting Dreyfus.

The point of France (1908) is to tell the history of France (that is, penguins) from the dawn of its history, when its residents were still faltering birds. On its way to the future, the book pauses over several famous episodes of French history. The longest chapter on this journey is devoted to the Dreyfus Affair, used to criticize French society.

Proust (1913-1927) is a thirteen-volume work, published between 1913 and 1927. In this work, Proust describes his life as an allegorical search for the truth, and paints a picture of the atmosphere and hypocrisy, intrigues, and doubts that prevailed in the wealthy classes in France at the end of the nineteenth century and in the Paris of his times. Jewish characters from his mother's family also feature in the book. In 1919, he was awarded the prestigious Prix Goncourt for the second part of this work. When France was in uproar over the Dreyfus Affair, Proust sided with Dreyfus's innocence and devoted one of the chapters in his book to the affair (see (Christophe, 1977)).

Harris (2013) is a historical thriller based on the Dreyfus Affair, published in 2013. The story is based on the Dreyfus Affair, but its plot is fictitious. In Paris of 1895, Georges Picquart, a young, ambitious officer, sees the convicted spy, Alfred Dreyfus, publicly humiliated before the angry masses, and sentenced to life imprisonment on Devil's Island. Picquart, who has just been appointed to head the intelligence unit that brought the evidence against Dreyfus, is certain of his guilt. But shortly after Dreyfus begins to serve his sentence, he starts having doubts. There are clues that the spy is still inside the army. When Picquart begins to investigate, he is swept up into a dangerous maze of deceit and corruption that raise doubts regarding everything in which he believes, and threatens not only his honor but also his life.

\subsection{The Background to the Creation of Literary Works about the Dreyfus Affair in Ladino}

The literary works in Ladino, written at the beginning of the twentieth century following, or against the background of, the Dreyfus Affair, were written for several reasons:

- Strengthening the Zionist Movement and the Jewish-nationalist ideal of returning to the Promised Land following the Young Turk revolution, as well as the desire to fight the Jewish opponents of Zionism. ${ }^{\mathrm{i}}$

- The struggle in the French Alliance Israélite Universelle schools, that operated around the Ottoman Empire while glorifying French culture; the literary works in Ladino about the Dreyfus Affair shatter the myth of an enlightened and progressive French culture.ii

- The lack of real literary texts around which the new secular-cultural identity could be formed (Holtzman, 2000). The Jewish-Sephardic world was undergoing a process that can be defined as a "cultural revolution" and, instead of seeking them out within the Jewish world, a search was now underway for ways of detaching from the old lifestyle patterns to expose themselves to Western culture. Organizations with a particular ideological-political stance began to appear on the JewishSephardic social scene and also influence their literary world.

- The writing of literary works in Ladino about the Dreyfus Affair is a part of the flourishing of literature in the Jewish-Sephardic culture of the beginning of the twentieth century, that emerged, 
among other reasons, as a result of the claim by Western Jewry that Eastern Jewry was sunk in the mire of depressive materialism and lacked lofty cultural-spiritual aspirations (Benbassa, 1996).

Consequently, the literary works in Ladino about the Dreyfus Affair were published in a stormy period for Jewish-Sephardic society. The loss of past tradition in the face of the Zionist vision; major demographic changes following the population changes between Turkey and Greece; the disintegration of the old regime of the Ottoman Empire, and modernization of education and academic studies. Alongside these geopolitical changes in the Ottoman Empire, this era also saw changes on the literary plane, and Ladino-speaking Jews began to develop new literary tools.

\section{Methodology}

The article will discuss several genres of literature in Ladino about the Dreyfus Affair during different periods: two historical novels, a play, and a newspaper article. While examining the correspondence and echoes between the different works.

\section{The Paper's Goal}

To reflect the literary expression of the Dreyfus Affair in Ladino literature and understand why these works were written.

\section{Findings and Discussion}

\subsection{The Ladino Historical Novels about the Dreyfus Affair}

The most thriving literary genre during the early twentieth century was historical-romantic, combining a Jewish apologetic theme with clear sentimental literary conventions (Shalhevitch \& Perry, 1975). Like historical poetry, the fiction of the time also allowed itself a liberal dose of poignancy. The topics of forced conversion and destruction, exile and expressions of greatness and heroism in the face of powerful forces of evil, were sprinkled liberally in the historical stories. The narrative technique possesses all the characteristics of sentimental intrigue.

For this discussion I have chosen two of the novels written in Ladino at the beginning of the twentieth century about the Dreyfus Affair: El Romanso Di On Inuginti [The Story of the Innocent] by Ardity (1901) and El Dreyfus Otomanu [Dreyfus the Ottoman] by Halevi (1909) both written in Rashi script (a typeface commonly used for printing biblical commentaries).

Ardity's El Romanso Di on Inuginti is a historical novel about the Dreyfus Affair itself, whereas Sa'adi Halevi's El Dreyfus Otomanu is a historical novel based on the case of Joseph Karmona, a Jewish doctor in the Turkish army who was falsely accused of having poisoned two Turkish soldiers. This novel was written as a kind of echo to Ardity's book that preceded it by eight years. Sa'adi Halevi also writes in the introduction: "Shem Tov Eliyahu Ardity wrote a novel about Dreyfus. And we also have our own Dreyfus, Dreyfus the Ottoman". This sentence was not intended to minimize the Dreyfus Affair, but rather to note the universality of antisemitism, that transverses countries, governments, and cultures.

Ardity's book is longer than Sa'adi Halevi's, but as the plot unfolds there are many points of similarity between the two main characters - Dreyfus and Karmona. Both are the victims of a false accusation, both cry out against the injustice against them, both bid farewell to their relatives before setting out to serve their sentence, both have supportive families who fight for their being declared innocent, both face a situation of near collapse and beg to die, both are saved at the last minute by a secondary figure, both write letters to various bodies to prove their innocence, both swear their innocence with the same words, "I swear to you that I am innocent. My sole crime is that I am a Jew", iii both ask to return to military service after their final trial. Even the ceremony where the accused is stripped of his rank appears in both novels-Dreyfus has his rankings torn from him, whereas Dreyfus the Ottoman-Karmona-is saved from this humiliating ceremony. However, the Jewish doctor who treats him until he recovers tells him once, "I was also a doctor in the Turkish army, and when I saw the humiliating attitude towards me as a Jew, I tore off my ranks, cast them to the floor, and left the army". This is a dialogue that defies the designers of the ceremony to humiliate the Jew-you won't humiliate me; I will do it myself and leave your racist company with disgust and my head held high. Harshav (2000) argues that the character speaking in the novel can show how something personally affects him, while also offering a value-based dimension and an ideological perspective. It is important to note that Karmona fought for twenty-one years to prove his innocence, far longer than Dreyfus, and this is mentioned in Sa'adi Halevi's novel: “The French Dreyfus spent five years on Devil's Island, but the Ottoman Dreyfus suffered far longer from the antisemitism" (Halevi, 1909).

Both novels open with the moment that the crisis is recognized. Both begin with criticism of societyArdity of French society and its racist government elite, and Sa'adi Halevi of the violent Turkish society, the judicial system built on bribery and the "beasts of prey" of the Turkish army: "the Turkish officers could not be compared to anything, not a tiger, not a lion, not any wild animal” (Halevi, 1909). ${ }^{\text {iv }}$ Sa'adi Halevi also uses the simile of an animal - he compares the Turkish elite, after having been bribed, to sheep.

When Karmona goes out and visits the Jewish cemetery before his trial, to gain strength and connect with his Jewish identity, he compares one of the gravestones to a white dove. Ardity uses images of beasts of prey, 
whereas Sa'adi Halevi uses those of the prey itself-a sheep and dove. The conflicts and contrasts between the predators and prey in both novels express the situation in the world we live in-rulers as against those controlled, accusers versus the accused, and haters versus those who are hated.

The works do not focus on the internal and external struggles of Dreyfus or Karmona, but rather on the endless longing for friendship when enveloped in intense loneliness, and the ceaseless need for social contact, conveyed by the words of yearning for distant family members. In Ardity's book, Dreyfus does this with a cry, "I am innocent, my brother, I am innocent, I swear!" (Ardity, 1901)v and with another cry when he is thrown into his cell, "They want to bury me here!" (p. 42) vi Sa'adi Halevi communicates Karmona's loneliness by describing his frequent tears: "One tear arose from his heart to his eyes, but did not emerge from between his eyelids. "Ben Karmona could not allow himself to appear so weak as to cry in front of another man" (Halevi, 1909) vii "The doctor kissed him on his forehead and allowed one of his tears to fall on the pearly tear of Yosef Karmoma” (p. 33); viii "His tears flowed" (p. 33). ${ }^{\text {ix }}$

These novels contain many contradictions and contrasting human characteristics so as to make the plot tighter and extend its significance. The creators conceal the essence of the survival of the Jewish nation and individual in the text, using direct speech that moves forward at the rate of speech and breath. If the sentence is lengthy, it is succeeded by a short one, to provide the place and musical possibility for a more packed sentence. The writing resembles the movement of a camera that moves at the speed of the events, interferes, focuses, or blurs. The reader sees progression as inevitable, as one thing leading to another-the suspicions, the accusation, the drumhead court martial, being thrown into jail.

The two novels, despite them directly and indirectly corresponding to the Dreyfus Affair and with each other, also correspond to other works by other authors, showing the authors to have been aware of other world literature. For example, the authors of both novels mention the French novelist and journalist, Victor Hugo. Ardity notes that Dreyfus's birthplace was that of Victor Hugo, and Sa'adi Halevi notes that Victor Hugo once wrote in one of his works: "The day will come when one flea will be able to say to the angel from heaven-sit down and we'll settle things between us" to describe a utopian state of equality among all people. Likewise, Ardity mentions several journalists who covered the affair. He notes that one of the American newspapers wrote that Dreyfus could have escaped from Devil's Island using money that his wife sent him, but he didn't do so; that the French newspaper, Le Figaro, suspected that Rothschild supported Dreyfus, and that the British newspaper, The Jewish Chronicle, published an article entitled "Three Years of Silence" supporting Dreyfus. From these and other reviews mentioned in the book, it seems that Ardity read many extraliterary materials as preparation for writing his novel, which includes both literary and documentary elements.

Ardity has a particular style of speaking to his audience. His writing is extremely emotional and he shares his feelings with his readers. He frequently uses the metaphor of a heart: "I will open my heart", x "only my heart knows", xi "a broken heart.xii When he describes the ceremony in which Dreyfus was stripped of his rank, he writes, "I feel fainthearted and I do not have the courage to write about this occasion" (Ardity, 1901) ${ }^{\text {xiii }}$ In another place in the novel, where he describes Dreyfus's prayer, he writes, "Writing any more is likely to arouse the weeping of our readers" (p.5 1). ${ }^{\text {xiv }}$ It seems that Ardity doesn't detach himself, as an author, from his work. He writes it in first person, lives it, breathes it, and senses the readers who accompany his writing. Possibly this is because his writings are the closest in time to the Dreyfus Affair, written just six years after it happened. As opposed to Sa'adi Halevi whose book was authored fourteen years after the affair.

There are two central themes emphasized in the novels, and they are connected to the question of the relationship between the antisemitic factor and the suffering Jew. One relates to the effect of the deeds of the echelons of the French or Turkish army on the entire Jewish community. Repeatedly, and using various speakers, the authors show how the physical and verbal violence by the heads of the army against one Jew and their racist way of thinking, permeates the society. The other issue that is raised again and again in the long dialogues and monologues by Dreyfus and Karmona concerns the individual's ability to change the situation he is in, even a little. Their hopes are dashed one after another, and they understand that the antisemitic logic is stronger than the efforts of one person. This is also the source of the power of several of the pictures in the novels. These scenes emphasize the dialogue between various worldviews, which are not only frequently entangled with each other, but even within themselves. The authors' literary-cultural trend served as a platform for a literary creation, with its limits determined in advance. They base themselves on a story that moves from an individual's personal crisis to a developmental change in the public, and thereby also invokes the common literary culture of the return to Judaism as part of redemption. The novels raise interpersonal relationships that are understood in emotional consciousness as a state of longing, a fixating thirst. The deeds and days of Dreyfus in the prison and of Karmona under house arrest seemingly add up without purpose: letters are sent and received; memories change without law and order, and only the constant desire "to bring justice to light", $\mathrm{xv}$ a key sentence in the books, burns within them. This is also the story of struggle and survival and of the loss of a Jewish identity that gradually disintegrates. Dreyfus, the hero of Ardity's story, is not the historical Dreyfus who is in the throes of assimilation. Ardity's Dreyfus prays, beseeches God, and is connected to his Jewish existence with his very soul. Ardity puts prayers and supplications to God into his mouth and even notes that "Alfred" (Dreyfus's first name) is actually "Albert" and "Albert" is "Abraham". Ardity chooses to end his novel with a verse from Psalms: "All the nations surround me; in the name of the 
Lord, I cut them down”. And Sa'adi Halevi ends with a reference to the Purim holiday-Karmona's wife says on the day he is cleared, "Today is Purim"- the festival on which the Gentile who plotted to incriminate the Jew eventually met his downfall and was incriminated himself.

We need to take into account that the authors' culture of birth was comprised of a mingling of the different ethnic, religious, conceptual, and lingual elements of the Sephardic-Jewish communities in the countries of the Mediterranean basin. Both writers include popular expressions that naturally move from spoken to written language. Here are some of the popular phrases appearing in Ardity's novel: "to look into the whites of my eyes" [to be close to me] (Ardity, 1901) "everything from top to bottom in his room" [a mess] (p.12); "their fingers point to one table" [they agree unanimously] (p.22); "buried alive" [he is better off $\operatorname{dead}$ ], "before they built the grave they tied up the victim" [an expression of a physical and irresponsible action] (p.38); "the French army was dragged through the mud" [suffered defeat] (p.57); "to dip Picquart in evil waters" [to incriminate him] (p.60). And in Sa'adi Halevi's novel: "in a place where they didn't check much for snakes" [they would close their eyes to corruption] (Halevi, 1909) "no one knew which law to dance to" [an expression of an anarchistic situation in the Turkish legal system] (p.40).

Ardity includes two Hebrew words within the Ladino: "tzedaka" [charity] (Ardity, 1901) and "mormoriar" (pp.53, 59) which means to resent or complain [the Hebrew verb lehitmarmer with the "ar" suffix in Spanish]. Sa'adi Halevi also inserts several Hebrew words: "malshinaseyunis", which means informing on someone (from the Hebrew word "malshin" with the plural Spanish "es" suffix), "bet hahaim" [cemetery] and "rabbanim" [rabbis] (Halevi, 1909). Both books also contain words from Turkish, French, and Greek, because that is the essence of Ladino and what differentiates it from Spanish and makes it Judaeo-Spanish-the inclusion of the languages of the Jewish Diaspora after the Exile from Spain into Medieval Spanish with which the Jews left Spain and that remained their language in their wanderings to the Balkan countries, where they added additional local expressions. The Hebrew component of the language testifies that the speakers of all the Jewish languages draw from the classical texts and the daily religious lifestyle; these are the words that become an inseparable part of the basic vocabulary in that language. Such citations that create speech with fixed expressions arise from the intertextual reality in which the speaker is in a Jewish society, and finds himself between texts from Jewish sources and those he produces himself (Bar-Asher, 2003).

The authors' motive for writing about the affair is clear to us. However, the test is not in the writing but rather the reading, meaning, in the ability of such a text to envelop, persuade, and draw in the reader. In the case of these two novels, written in Ladino about the Dreyfus Affair, reading is particularly significant, since the reader constantly compares the books by Ardity and Sa'adi Halevi.

\subsection{The Ladino Plays About the Dreyfus Affair}

The play "Dreyfus" by Loria (1903) is a drama which integrates many components of the affair, some factual and some fictional. It begins with a dialogue between the two true spies, showing us the motives for the spying, how the evidence was tampered with and placing the blame on a Jew, including expressions of hate and jealousy, and antisemitic and racist name calling. The antisemitism is the seed, around which Loria created his play, and made it a cornerstone for the social and Jewish dimension. All the characters in the play, first and foremost Dreyfus, embody this principle. Even the characters who are diametrically-opposite to Dreyfus transmit the same clear message. The starring role, reserved for the humiliated, suffering Jew and his trust in God, is given to Dreyfus. From the first scene, it is clear to everyone that all the evil that befell him is solely because he is a Jew. The other characters in the play all reinforce this idea, and the way the drama is staged and how the figures are represented already contain the basis for its development.

There are ups and downs throughout the play. At the most critical moment, a wondrous rescuer appears: Lucy, Dreyfus's wife, saves him from committing suicide at the last moment. The prison warden tells him of his release after a scene showing Dreyfus's hopeless request to a flock of birds who fly past the window of his prison on Devil's Island. The drama is full of emotion from beginning to end-it includes jealousy, hate, love, fear, anger, sadness - the entire gamut of emotions that serve as a literary device intended to win the viewer's empathy and identification with the characters.

The play includes liberal use of psychologism. It includes a stream of conscience, and what drives the play narrative is the awareness of the main character: the figure of Dreyfus, sometimes anxious, sometimes depressed, sometimes hysterical, who lives with an obsession regarding his relationships - as a father, son, and husband. It imparts his prison stay with endless thoughts about his parents — symbolizing the past, childhood memories, and nostalgia, and his children-who symbolize the new generation.

"Dreyfus", by Afia (1928) is a handwritten, unpublished drama made into a performance. ${ }^{\text {xi }}$ The play was staged in Istanbul in 1932 (in Ladino), 1947 (Turkish and Ladino), and in Israel in 1953 (Ladino). The play was not staged for commercial reasons, but for social goals of culture, passing on a message, and preserving the language. ${ }^{x v i i}$ The actors were amateurs, not seeking remuneration, from within the community, for whom the performance was an experience. Afia and the actors did not anticipate fame or admiration, it was enough for them that people came to watch the play. They staged the play with a sense of mission and love for their ancestors' culture, and not because they wished to gain recognition for their creation. Afia's play transformed Loria's play into a live storytelling event. The string of dialogues and monologues create a rhythmic dynamic, 
resembling heartbeats, increasing the tension when they are short, and arousing the audience's emotions (empathy and identification between loathing and rejection) when they are long.

Afia uses the exposition for confrontation from the beginning to the close, with each character having its own special rhetoric: Fabris's toughness, Dreyfus's emotions, Esterhazy's self-confidence, Picquart's honesty, and Zola's determination. The narrator already declares at the beginning of Afia's play:

"Who is Alfred Dreyfus? Alfred Dreyfus was an officer in the French army, and after he had married and was the father of two children, in 1894, he was the victim of antisemitism".

This exposition did not appear in Loria's play. An opening like this immediately draws the audience into the atmosphere that the playwright is interested in creating, and the message he wishes to convey: antisemitism. Later Fabris appears, with him looking through the list of employees in the army headquarters, to find someone whom he can tar with the blame in his place, "Lavinein, La Pierre, Kazmir, DuPont, Dreyfus, Chinchal... Dreyfus? A Jew? Yes, a Jew! The only Jew in the army headquarters! How did I not think of that? How didn't I notice? A Jew! A Jewish officer! Who is more likely than a Jew to be a traitor to his country of birth? Who won't believe that this Jew is a spy? Really, I was so stupid! Why did I need to search so much? Two feet away from me is Dreyfus, the only Jew who has entered the army headquarters until now...”

In these four sentences, Fabris mentions the fact that Dreyfus is a Jew eight times. The poetic goal of these repetitions, which appear in the plays of both Loria and Afia, is to emphasize in a way that cannot be misunderstood - the hatred here is to Judaism as a religion. Fabris does not create the antisemitism. It already exists and assists him in his plot to incriminate Dreyfus. Later Fabris says, "Judas Iscariot was a Jew! If he sold our lord Jesus for thirty silver coins, who won't believe that another Jew sold his country of birth for money?"xviii

Afia skips over this passage in his play. Perhaps he wanted to avoid touching on Christian issues, that were less relevant for the Jews of Turkey, living under Muslim rule, than for the Jews of Sophia (Loria's place of writing), who lived among Christians. Perhaps he saw emphasizing the antisemitic issue in this passage as superfluous, and something that could harm the Jews when it was staged publicly. Or perhaps he wanted to avoid the comparison that they would make between Jesus (who was originally a Jew and openly declared that he was the messiah of the Jews) and Sabbatai Zevi (1626-1676), a false messiah from Turkey, who founded the largest messianic movement in the history of Judaism. These racist claims regarding Jewish greed for money add authenticity to the play, but they also play an important role in transmitting the playwright's covert message to his audience: the Dreyfus Affair does not provide immunity from antisemitism. Such comments about Jews and their money can sometimes be heard here too, in the Balkans. It is not difficult to make libelous remarks about Jews, and the affair can be repeated in one or other variations.

The task of telling a theater audience the content of a play and its character is very difficult. Apart from natural aptitude, a person also needs techniques, self-discipline and rehearsals over a long period. The text is written by the playwright, but the subtext must be created by the actor. Afia condensed Loria's lengthy instructions to the actors that appeared in parentheses in Loria's play and made efforts to choose actors who were physically and vocally suitable, and with appropriate acting talent.

Romero (1980) dedicated an important study to folk plays in Ladino. She made great efforts to locate information about the theater and theatrical activity in Judaeo-Spanish. Romero based her bibliography on personal reports, biographies, historical and literary research, and, of course, the actual plays. In her book she classified the Ladino plays according to types of work, subjects, and author names, and listed 640 works. Romero notes that the most popular subjects were Joseph and his brothers, Esther, and the Dreyfus Affair. She reached this conclusion from findings regarding the large number of titles discussing the affair: "Dreyfus", "Alfred Dreyfus", "Captain Dreyfus", and others. She noted that the plays were staged in different places and periods. The Dreyfus Affair was close to the hearts of the Sephardic Jews in Thessaloniki, Istanbul, Izmir, and Sophia. This large number of such plays by Sephardic Jews is surprising, particularly in light of the silence of the Jews of France themselves during the affair. French Jewry steadfastly continued expressing its loyalty to its motherland and the values of the French Revolution, and shied away from openly working for its fellow religionist, Alfred Dreyfus. This Jewish community was then in the throes of assimilation, that demanded adopting the behavior of the surrounding society and keeping silent until the affair had blown over. Aside from which, all Dreyfus's defendants in both the literary works and reality were actually Gentiles. If French Jewry was silent, what motivated Sephardic Jews from the Balkans to write about the affair? We will attempt to briefly answer this question in the summary.

\subsection{The Newspaper Article "El Antisimitizmo Y El Kavzo Dreyfus” by Solomon Bejerano}

In the newspaper article, "Antisemitism and the Dreyfus Affair" by Solomon Bejerano (Shalom, Turkey, 1994) a covert message appears designed to awaken the Sephardic Jewish readership in Istanbul to the issue of antisemitism. This article is particularly interesting in light of the fact that, as noted above, the earlier literary works on the affair were written at the beginning of the century, when the affair was still at center stage of Jewish awareness. Bejerano looks back on the twentieth century - a century of destruction and blood, of genocides in the name of ideology and the slaughter of millions of people because of their beliefs, race, color, and being different, and seems to shatter the hope of the earlier writers for a better world without 
antisemitism. The subtext of Bejerano's article hides a clear goal of warning about the seeming tranquility and comfort of the Jews of Turkey at the time, who deny the antisemitism that still exists in their places of residence. The reader needs to remind himself that the common denominator of this entire eclectic article is supposed to meet the goal of the writer that already appears in the title, "Antisemitism and the Dreyfus Affair". The main topic is antisemitism, with the Dreyfus Affair being secondary and serving only as an example. In parallel, Bejerano polishes the Ladino language with the intention of bringing the Spanish wrapping of his article to its greatest objective ability as a Ladino speaker (and subjective, by translating several Ladino words into Turkish, testifying to how Ladino language skills had become weaker and Turkish stronger among the readership). Unlike the earlier authors, he refrains from labels or popular expressions. It should also be noted that Bejerano's messages are even more disguised only because of the nature of the writing. The earlier authors wrote Ladino in Hebrew letters (Rashi script), but Bejerano writes in Latin letters, which are easier for the readers of his time to understand. However, that also meant that members of the government would also find it easier to understand, and Bejerano is afraid of such a scenario.

\section{Summary}

Unlike the allegorical novels about the affair and its aftermath in world literature, Ladino literature continued to take the well-trodden path of realistic, detail-laden writing, which leaves no room for interpretation. The authors of the novels, plays, and article in Ladino examined in this article, write Dreyfus's personal biography together with constant dialogue regarding antisemitism. They fire graceful, sensitive and intellectual arrows, which lead the reader to two intertwined discussions. One about Dreyfus himself and his life. The writers are in the position of narrators who look inside, drawing on advice and multidimensional reference to all known manifestations of antisemitism in history and literature, on both the individual, psychological plane, and the social one. The other discussion is the really informative one. This is a personal and daring discourse with the Jewish tragedy in general, and the individual within the nation. This individual sins by denying his origin, matures, experiences painful stages during which he slowly becomes aware of himself and his deeds, and even his human failings, until he redeems himself after becoming totally aware of everything significant for him.

Dreyfus's life story (and that of "Dreyfus the Ottoman"-Karmona) can be sketched as a line drawn between two wars with a traumatic effect on the Jewish experience- the war against antisemitism in general, and the war against the aims of the Alliance Israélite Universelle, representatives of French culture, throughout the Balkan countries. One was experienced as a trauma passed on from one generation to the next, and the other was directly experienced as group helplessness. Each writer provides his book with a framework that serves the eternal discussion with the biographical-personal- "truth" of each person, and how it is examined in the light of the truth in reality. The literary works were written on the dividing line between cultures and generations. The authors accompany the hero who walks this explosive line, intimidated by the drop on either side, but who survives despite everything. The well-defined and rich personal-human experience is realized literarily by the authors. The literary works in Ladino about the Dreyfus Affair are unique in that they discuss a story that creates awareness and defines identity. The authors examine and experience the dilemmas, and even bring us to experience them together with them. They wish to give us more than one version, and wonder about the solution; and thus narrator and reader are equal in rank, and the story is the interaction between them. They are constantly busy shaping the story, while being aware of the result and its implications. Despite the effect of words, despite the centrality of Ladino to the text, it seems that the writers award first place to emotions, to the emotional essence, and nonverbal deeds. Perhaps the writers are telling us that even if language is inborn, even if the two stories have eternal messages, there is still a world, there is truth, there is love and pain, and the narrator is just someone with an existentialistic view, who fills an ancient need. The Ladino writers swung between isolation and contact with their surroundings. They absorbed materials from their environment and worked in its world of context. However, they also gave over content to their environment, created their own content based on what they had absorbed, and were figures in the public setting of their culture, Sephardic-Jewish culture, that was the base from which they departed and to which they returned.

\section{References}

Afia, E. (1928). Dreyfus. Unpublished Manuscript. Istanbul.

Ardity, E. S. T. (1901). The story of the innocent. Thessaloniki.

Bar-Asher, M. (2003). Studies in research of the Jews and their books. Pe'amim, 93, 77-91.

Benbassa, E. (1996). Ottoman Jewry between westernization and Zionism, 1908-1920. Jerusalem: ZalmanShazarLetoldotYisrael.

Benbassa, E., \& Rodrigue, A. (1993). The Jeres of the Balkans: The Judeo-Spanish community, 15th to 20th centuries (Jerwish communities of the modern world. Oxford, England and Cambridge, Massachusetts: Blackwell.

Christophe, C. (1977). Literary field and field of power, writers and the Dreyfus affair. Annals, Economies, Societies, Civilizations, 32(2), 240-264.

Dori, N. (2007). El Maccabeo - Sketches of a literary-Zionist annual in Ladino, Thessaloniki (1914-1931). Unpublished Doctoral Dissertation, Bar-Ilan University, Ramat Gan, Israel. 
France, A. (1902). Monsieur bergeret in Paris. Paris: Calman Levy.

France, A. (1908). Penguin Island. Paris: Calman Levy.

Halevi, S. S. (1909). Dreyfus the Ottoman. Thessaloniki: Record: The National Library of Israel.

Harris, R. (2013). An officer and a spy. London: Alfred A. Knopf.

Harshav, B. (2000). Fields and frames: Essays in the theory of literature and meaning (Selected Writings) (Vol. 1). Jerusalem: Carmel.

Holtzman, A. (2000). Aesthetics and national revival: Hebrew literature against the visual arts. Haifa: Haifa University, and Tel Aviv: KinneretZmora-Bitan.

Kleeblatt, N. L. (1987). The Dreyfus affair: Art, truth, and justice. California: University of California Press.

Loria, J. (1903). Dreyfus. Sofia.

Proust, M. (1913-1927). In search of lost time. Paris: Grasset.

Reuven, S. (1984). The Zionist movement in Thessaloniki, from then until now, cathedra lectures (1977-1983). Tel Aviv: Tel Aviv University.

Rolland, R. (1898). The wolves. Paris: Bellais.

Romero, E. (1980). The theater of the Southeast (Vol. 3). Madrid: CSIC.

Shalhevitch, B., \& Perry, M. (1975). Simon Halkin jubilee volume. BneiBrak: HakibbutzHameuchad.

Zola, E. (1903). Truth. Paris: Bibliotheque Charpentier.

i. Regarding this, and regarding the Westernization processes of the Sephardi Jews, see at length in Benbassa and Rodrigue (1993). Regarding the opponents to Zionism, and their leader, journalist David Fresco, editor of the El Tiempo daily paper in Turkey from 1871-1930, see at length in Reuven (1984).

ii. We can learn about this struggle by studying Zionist-literary journals in Ladino published in Thessaloniki during the early twentieth century, such as El Maccabeo and El Jidio. See Dori (2007).

iii. "Vos juro ke so inochente, mi solo krimen es de ser Judio."

iv " "Eyos no se pudian apariguar a nada, ni al tigre, ni al leon, ni a ningun animal salvaje."

v. "Yo so inochente ermanos, so inochente, lo juro."

vi " "Es aki ke me keren enterar."

vii. "Una lagrima suvio del korason a los ojos, ma eya no salio afuera de las parparas. un karmona no pudia mostrarse flako asta el punto de yorar delantre otro ombre."

viii. "El mediko le puzo bezo sovre la frente, en deshando kayer una lagrima ke fue konfonderse justo kon otra perla ke suvia a la parpara de yosef effendi."

ix " Tuvo una fuerte kriz de lagrimas."

x. "avrire mi korason"

xi "solo mi korason save"

xii "korason arazgado"

xiii. "me manka el koraje para deskrivie la shena"

xiv. "seria azer yorar a muestros meldadores"

xv. "kitar la justisia a luz"

${ }^{x v i}$. The author currently has has the play on loan, thanks to the family's generosity.

xvii. Told to me by Yisrael Levi (1924-2010) who played the part of Dreyfus in the play.

xviii. Judas Iscariot, according to the Christian tradition, was one of the twelve disciples of Jesus, to whom Jesus entrusted spreading his teachings. After Jesus' Last Supper, his disciples turned to Gethsemane on the Mount of Olives. There one of his disciples, Judas Iscariot, betrayed him to the Romans, for thirty silver coins. The Roman governor ordered Jesus' death by crucifixion. 